\title{
Study and Comparison of Working Memory Components in Autism and Normal Children
}

\author{
Sara Aghababaei ${ }^{1}$, Maryam Samadi ${ }^{2}$ \\ 1-Ph.D in Psychology, Lecturer of University, Isfahan, Iran. ORCID: 0000-0002-9430-5715 \\ E-mail: sara.aghababaei@ymail.com \\ 2- Ph.D Student in Psychology and Exceptional Children of Isfahan University, Isfahan, Iran. ORCID: 0000-0002- \\ 7393-9065
}

Received: 21/04/2018

Accepted: 07/10/2018

\begin{abstract}
Introduction: Cognitive processes deficits is considered a common feature of autism spectrum disorder, it seems that any deficit in this processes might impact on the abilities and behaviors in this group.

Aim: The aim of this research was study of working memory components in autism children and comparison with normal children.

Method: The design of this research was ex post facto that done on 40 children aged 4-6 (20 autistic and 20 normal children).Sampling method for Autism children was available and for normal children was multistage random sampling method. The instruments were Autistic Behaviors Assessment Scale, Direct Digit Span, Indirect Digit Span, Corsi Blocks Task. Data were analyzed by ANOVA.
\end{abstract}

Results: The results showed that there is a significant difference between autism children and normal in central executive, phonological loop and visual-spatial sketchpad components of working memory.

Conclusion: Children with autism had deficits in working memory components. This problem should be assessed in order to plan appropriate interventions in autism children based on components of working memory.

Keywords: autism, central executive, phonological loop, visual-spatial sketchpad

How to cite this article : Aghababaei S, Samadi M. Study and Comparison of Working Memory Components in Autism and Normal Children. Shenakht Journal of Psychology and Psychiatry. 2018; 5 (4): 40-51 .URL : http://shenakht.muk.ac.ir/article-1-402-fa.pdf

Copyright () 2018 the Author (s). Published by Kurdistan University of Medical Sciences. This is an open access article distributed under the terms of the Creative Commons Attribution-Non Commercial License 4.0 (CCBY-NC), where it is permissible to download, share, remix, transform, and buildup the work provided it is properly cited. The work cannot be used commercially without permission from the journal. 


\section{بررسى و مقايسه مولفه هاى حافظه فعال در كودكان اوتيسم و عادى}

\section{سارا آقابابايى'، مريم صمدى'}

ا.د كتراى روانشناسى و مدرس دانشگاه، اصفهان، ايران. ايميل: sara.aghababaei@ymail.com r. دانشجوى د كترى روان شناسى و آموزش كود كان استثنايى دانشگاه اصفهان، اصفهان، ايران.

\section{جكيده}

مقدمه: نقايص فر آيندهاى شناختى، ويز گى معمول افراد با اختلال طيف اوتيسم است و به نظر مىرسد هر نقصى در اين فر آيندها

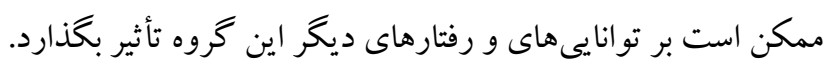

هدف: در همين راستا اين يُزوهش با هدف بررسى مؤلفههاى سه كانه حافظه فعال در كود كان اوتيسم و مقايسه با كودكان عادى صورت گ خرفته است.

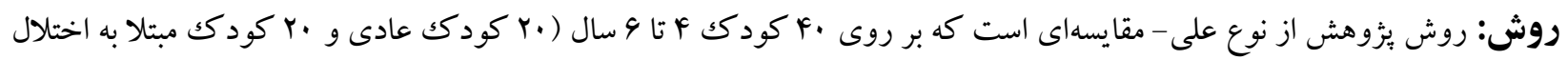

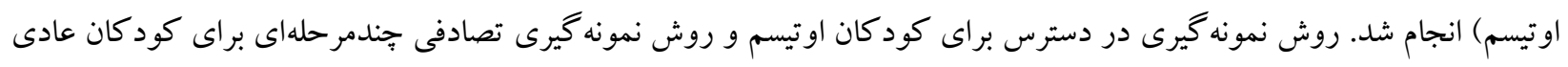

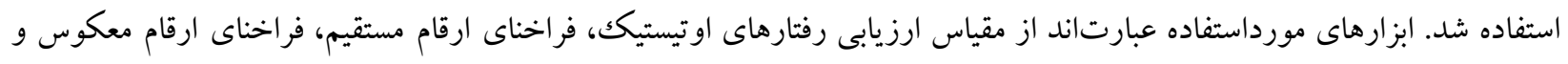

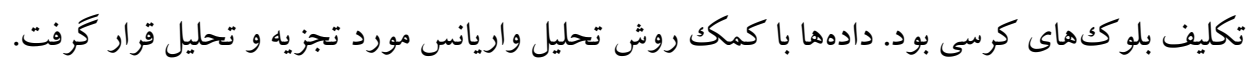

يافتهها: نتايج حاكى از آن است كه تفاوت معنادارى بين دو گروه در مؤلفههاى مجرى مر كزى، حلقه واجشناختى و الكوى ديدارى -

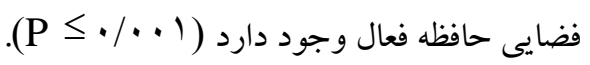
نتيجه گيرى: با توجه به عملكرد هايين مؤلفههاى حافظه فعال در كود كان او تيسم در مقايسه با كود كان عادى، از مداخلات مبتنى بر

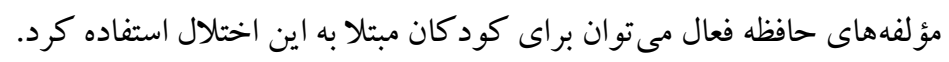
كليد وازه ها: وتيسم، مجرى مركزى، حلقه واج شناختى، الكوى ديدارى-فضا يى 
ندارد كه اختلال اوتيسم هريكك از اين عملكردها را دقيقاً به روشى يكسان تحت تأثير قرار دهد (ترت و و

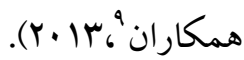

در ميان مؤلفههاى متعدد كاركردهاى اجرايى، حافظه

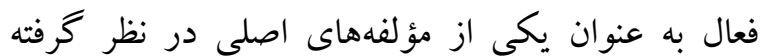
مىشود. حافظه فعال يكى از توانايىهاى شناختى سيال بوده و به مكان فعال ذهنى اشاره دارد. جايى كه اطلاعات مىتوانند به مدت كوتاهى از زمان در جريان فعاليتهاى شناختى ذخيرهسازى و دست كارى شوند (رابرت و همكاران"، 111). (1). در حوزه حافظه فعال يكى

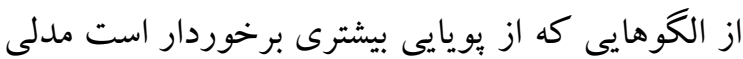

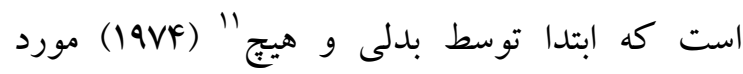
مفهومسازى قرار گرفت و بعدها به وسيله بدلى (Y... (Y) توسعه داده شد (جردن، كارلين واستاك، ترجمه

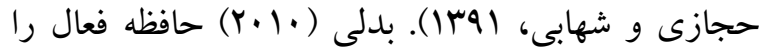
مشتمل بر r مؤلفه مىداند: حلقه واجشناختى با، الخُى

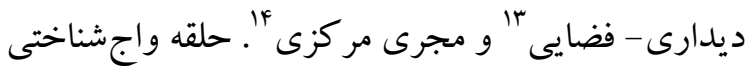
يكك انباره حيطه خاص است كه اندوزش موقتى اطلاعات كلامى و شنيدارى را بر عهده دارد. اين زير مؤلفه، براى فراگيرى زبان بسيار لازم است (ككوبو ها و

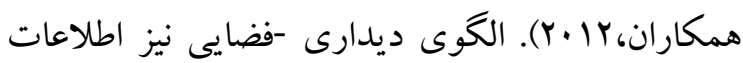
ديدارى - فضايى را ذخيره مى كند. گرجهه الكوى ديدارى - فضايى، خود به عنوان يكك زير مؤلفهى واحد در نظر گرفته مىشود ولى مى تواند به دو زير مؤلفهى جزئىتر تقسيم گردد؛؛ بينايى و فضايى. زير مؤلفهى بينايى، مسئول ذخيرهسازى اطلاعات بينايى (براى مثال

9 - Terrett et al

${ }^{10}$ - Robert et al

11 - Baddeley \& Hitch

12 - Phonological loop

13 - Visuo-spatial sketchpad

${ }^{14}$ - Central executive

15 - Kokubo

\section{مقلممه}

اختلال طيف اوتيسم'، اختلال عصبى -رشدى ' است كه بر اساس دو محور رفتارى؛ تأخير يا نقص در ارتباط تعامل اجتماعى و رفتارهاى تكرارى و علايق محدود

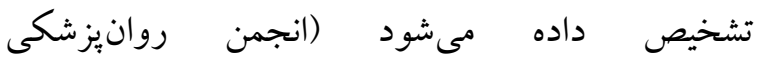

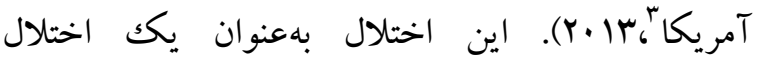
بيولوزيك در رشد نورولوزيك در نظر گرفته شده و علاوه بر علائم تشخيصى، ساختارهاى مغزى غيرطبيعى

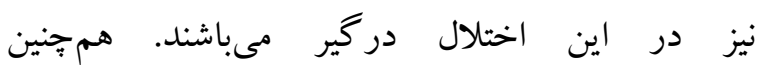
نابهنجارىهاى شناختى در اين گروه از افراد مشاهده شده است كه اين موضوع به نوبه خود اهميت نقايص شناختى و ارزيابى آن در كود كان با اختلال طيف اوتيسم را آشكار مى سازد (اسكميتز و همكاران، 9. ؟؛ به نقل از نجاتى و ايزدى، (9r()). در حوزه شناختى، اختلال طيف اوتيسم با نقايصى در توانايىهايى همجِون تئورى ذهن

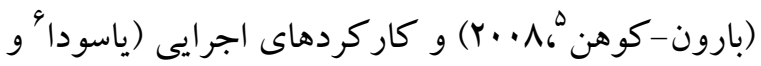

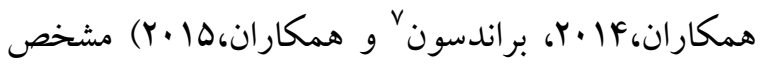
مىشود كه ممكن است نشانهاى رفتارى خاص اين اختلال را موجب شوند. اصطلاح كاركردهاى اجرايى، اصطلاحى است جامع كه مى توان آن را به عنوان عملكردهاى شناختى مرتبه بالاتر تعريف كرد و شامل مهارتهاى جند برنامهريزى، بازدارى، انعطافيذيرى شناختى، حافظه

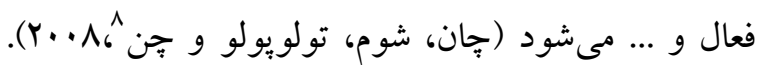
هر عملكردى شامل شبكه بيديجيدهاى از نواحى مغز و فرايندهاى شناختى متعدد است. ليكن اين احتمال وجود

1 - Autism spectrum disorder(ASD)

${ }^{2}$-Neurodevelopmental disorders

3 - American Psychiatric Association

${ }^{4}$-Theory of mind

5 - Baron-Cohen

${ }^{6}$ - Yasuda

7 - Brunsdon

8 - Chan, Shum, Toulopoulou \& Chen 
كود كان هستند (ويليامز، كلدشتاين، كارينتر و مينشوَ'،

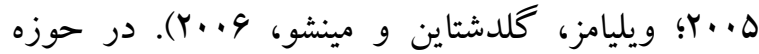
حافظه فعال كلامى، بثزوهشگ ان اذعان مىدارند؛ وقتى بار حافظه فعال حداقل است، افراد داراى اوتيسم هيج اختلالى در حافظه فعال كلامى ندارند (كوى، گائو، جن،

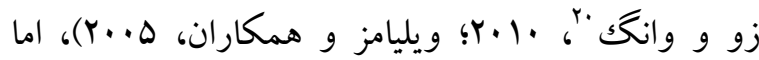
وقتى حجم زيادى از اطلاعات بيجيجيده بايد بردازش شود، اين افراد نواقص حافظه فعال كلامى را نشان مى دهند (ويليامز و همكاران، 9..ب). افزايش بار حافظه فعال در كود كان اوتيسم نسبت به كودكان داراى رشد طبيعى اختلال بيشترى ايجاد مى كند (كوى و همكاران، • (Y). اين نواقص را در گروههاى سنى مختلف گز ارش مى كنند

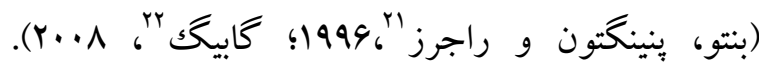
علاوه بر اين حافظه فعال ديدارى- فضايى نيز در اين افراد

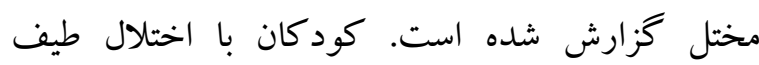
اوتيسم در ذخيره، حفظ و بازيابى اطلاعات ديدارى-

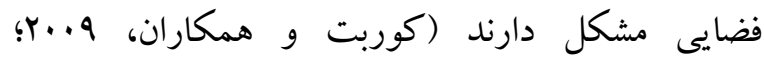

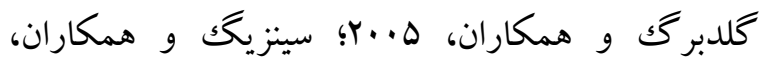

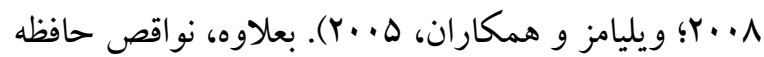
فعال ديدارى- فضايى به نظر مىرسد با علائم اوتيسم در

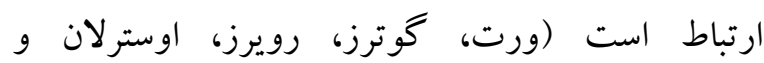

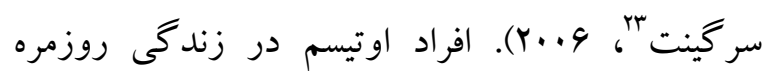
اغلب از تصاوير، نمادها يا شمايل براى نشان دادن كارهايى كه بايد انجام شود و رويدادهايى كه در طول يكك روز يا دوره زمانى خاصى اتفاق خواهد افتاد،

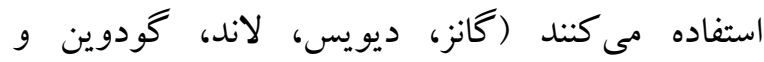

اطلاعات مربوط به شكلها و رنگگها) و زير مؤلفهى فضايى، مسئول ذخيره كردن اطلاعات فضايى (براى مثال اطلاعات مربوط به جهات) هست (بدلى، 9..ب). مجرى مركزى نيز يكك سيستم نظارتى است و براى كنترل و تنظيم كردن فرايندهاى شناختى به كار مىرود .اين بخش موجب جلب توجه به سمت محرك مى شود و مواردى كه بايد ذخيره شوند را مشخص مى نمايد

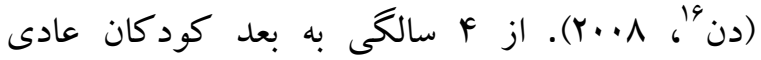
عملكرد مؤلفههاى مختلف حافظه فعال را از خود نشان

$$
\text { مى دهند (ملكك يور و آقابابايى، سا •Y). }
$$

در مطالعات بيان مى شود كه حافظه فعال در موقعيتهاى مختلف زندكى روزمره و تحصيلى حائز اهميت است. سواى از اين نقش بديهى حافظه فعال، نواقص اين نوع از حافظه نيز ممكن است رفتارى خاص را تحت تأثير قرار دهد. بعلاوه، براى يكك ارتباط اجتماعى مطلوب، به خاطر آوردن، بردازش و تفسير اطلاعاتى جون جهره فرد، ظاهر اجتماعى، لحن صدا و زبان بدن لازم است. اين ابعاد مختلف تعامل اجتماعى، نيازمند حافظه فعال است

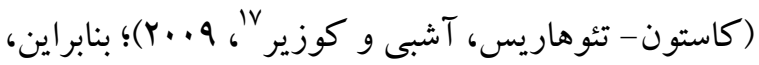
وقتى افراد داراى اختلال اوتيسم با نواقص حافظه فعال مواجه مى شوند، براى عملكرد روزانه خود دجار مشكل مى موند. نتايج يزوهش ها در سالهاى اخير نشان مىدهد كه افراد داراى اوتيسم نواقصى را هم در حافظه فعال كلامى و هم ديدارى- فضايى نشان مى دهند (ويلكات ^" و همكاران،

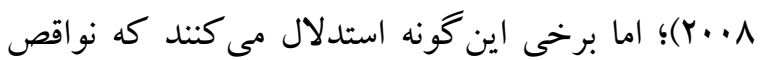
حافظه فعال ديدارى- فضايى، مهمترين نواقص در اين

19 - Williams, Goldstein, Carpenter\& Minshew

20 - Cui, Gao, Chen, Zou \& Wang

21 - Bennetto, Pennington \& Rogers

22 - Gabig

23 - Verté, Geurts, Roeyers, Oosterlaan
16 - Dehn

17 - Causton-Theoharis, Ashby \& Cosier

${ }^{18}$ - Willcutt 
به دنبال بررسى مؤلفه هاى حافظه فعال در افراد با اختلال طيف اوتيسم و مقايسه آن ها با كود كان عادى است.

روش نوع مطالعه در اين ويخوهش على-مقايسه ايى (يس رويدادى) هست. جامعه آمارى ئزوهش شامل كليه كود كان اوتيسم و عادى \& تا 9 سال شهر اصفهان در سال هوسا مىباشند. جهت انتخاب كود كان مبتلا به اوتيسم تعداد · r كودك اوتيسم از دو مركز اوتيسم شهر اصفهان انتخاب شدند. انتخاب اين مراكز به طور غيرتصادفى و

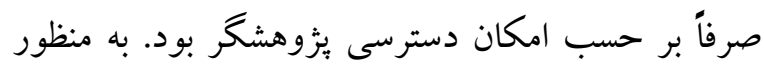

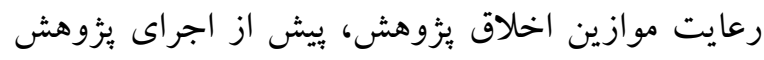
با مسئولين و والدين كود كان هماهنگى صورت گرفت و رضايت آنها كسب گرديد. ملاككهاى ورود به يزوهش براى كودكان اوتيسم شامل كودكان F-4 سال، برخوردارى از ملاككهاى تشخيصى اختلال طيف اوتيسم بر اساس ينجمين راهنماى تشخيصى و آمارى اختلالات روانى و مقياس ارزيابى رفتارهاى اوتيستيك، عدم وجود آسيب مغزى و اختلالات ديخر (با مراجعه به يرونده هاى آن ها) بود. ملاكك خروج نيز شامل وجود آسيب مغزى و اختلالات ديكر به غير از اختلال طيف اوتيسم بود. هم جنين به منظور انتخاب كودكان عادى از روش نمونه گيرى تصادفى خند مرحله اى استفاده گرديد. بدين شكل كه با مراجعه به اداره آموزش ويرورش شهر اصفهان يك بك بك

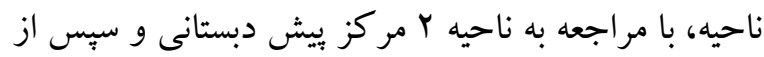

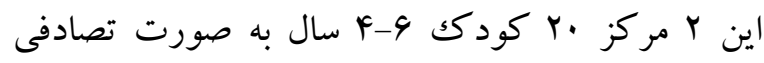
انتخاب گرديدند. ملاكك هاى ورود براى كود كان عادى عبارتاند از كودكان سنين F-9 سال، داشتن هوشبهر نرمال، نداشتن هر گونه اختلال بينايى، شنوايى و كفتارى آشكار و ملاككهاى خروج نيز شامل داشتن ناتوانى

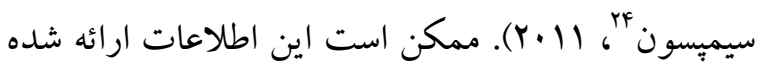
ديدارى، تأييدى بر رشد كمتر حافظه فعال ديدارىفضايى در آنها باشد (كورت، وريز و ون در در

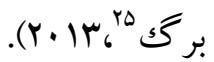
نواقص حافظه فعال در افراد اوتيسم به نظر مى رسد منجر به مشكلات عديده اى در ارتباط با تعديل رفتار، انعطافيذيرى شناختى، تفكر انتزاعى، تمركز و حفظ

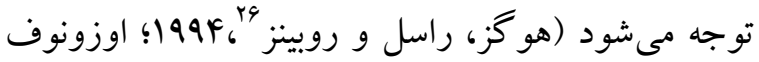

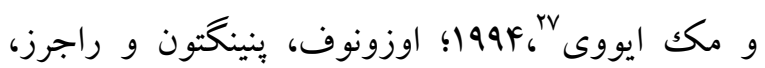
(1991). با اين وجود، يزوهش هاى قبلى متناقض بودهاند و همه مطالعات نقايص حافظه فعال كلامى (ويليامز و

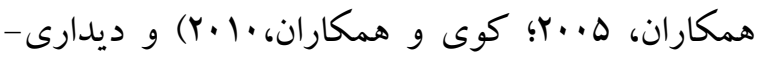

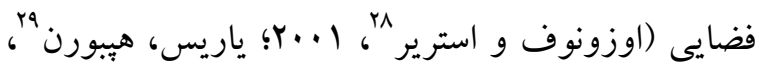

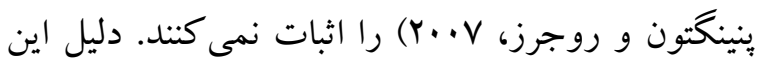
امر احتمالاً تنوع زياد در ويز گیىهاى افراد داراى اختلال اوتيسم و مفاهيم اين ويثز گیىها در روالهاى ارزيابى است. ليكن شواهد مبنى بر اينكه مشكلات واقعى در اين حوزه وجود دارد بسيار متقاعدكننده هستند (كوربت و و

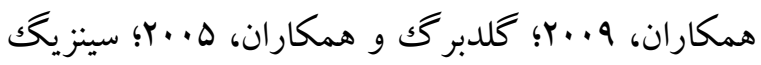

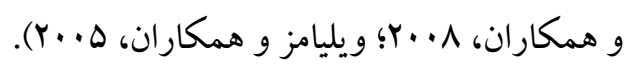

در راستاى مطالب فوق و اهميت حافظه فعال در موقعيت هاى مختلف اجتماعى، تحصيلى و رفتارى از يكك سو و همجنين خلأهاى إزوهشى در اين زمينه و استفاده از نتايج اين هُوهش در زمينه مداخلات شناختى همكى از ضرورتهاى مهم اين مطالعه است. لذا يزٔوهش حاضر

\footnotetext{
24 - Ganz, Davis, Lund, Goodwyn \& Simpson

25 - Geurts, Vries,van den Bergh

26 - Hughes, Russell \& Robbins

27 - Ozonoff., \& McEvoy

28 - Strayer

29 - Yerys, Hepburn
} 
مطالعات نشان مىدهند كه اين تكليف، ابزار مناسبى براى سنجش مؤلفه ديدارى- فضايى حافظه فعال و كو تاهمدت

$$
\text { است (كسل و همكاران، .... (Y.). }
$$

فراخناى ارقام مستقيم: آزمايشگر يك سرى اعد اعداد تك رقمى تصادفى را مىخواند و آزمودنى بايد اعداد را به همان ترتيب كفته شده تكرار مى كرد. سرى اعداد ابتدا دو رقم داشتند و بعد از هر بار ارائه، يكك رقم به زنجيره اضافه مى شد تا زنجيره، حداكثر هفت رقم شود. آزمون زمانى قطع مىشد كه كودكى دو بار متو الى يكك زنجيره را نادرست تكرار مى كرد. عملكرد به عنوان تعداد كل سرىهايى كه بهدرستى يادآورى مىشدند نمره گذارى مىشد .اعتبار آزمون- باز آزمون فراخناى ارقام در تحقيق كتركول و همكاران (Y...F) |N/ • است. از اين تكليف به منظور ارزيابى مؤلفه حلقه

واجشناختى حافظه فعال استفاده شد. فراخناى ارقام معكوس: روش اجراى اين تكليف مثل فراخناى ارقام مستقيم بود به جز اينكه كودكك بايد ارقام را به ترتيب معكوس ارائه آنها يادآورى

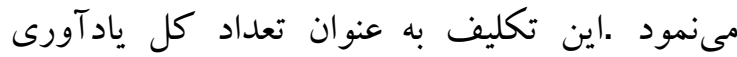
درست، نمره گذارى مىشد .اعتبار آن با روش آزمون-

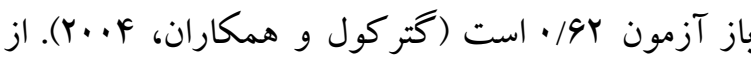
اين تكليف به منظور ارزيابى مؤلفه مجرى مركزى حافظه فعال استفاده شد.

\section{مقياس ارزيابي رفتارهاى اوتيستيك(ECA) لبّ اين} مقياس از هو سؤال تشكيل شده است و نمره گذارى آن نيز از طريق مقياس ليكرت است. به طورى كه اخر آزمودنى اين رفتارها را نداشته باشد صفر مى گيرد و اخر برك رفتارها شديد باشند، حداكثر نمره f دريافت مى كند؛

\footnotetext{
${ }^{30}$ - Echelle de Comportement Autistique
}

هوشى و اختلال بينايى، شنوايى و گفتارى آشكار در

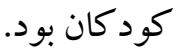

ابزار تكليف بلوكىهاى كرسى: سنجش مؤلفه ديدارى - فضايى حافظه فعال و كوتاهمدت از طريق نگه داشتن الخوهاى ديدارى با توالى حركات صورت مى گيرد. يكى از تكاليفى كه حافظه ديدارى- فضايى را اندازه مى گيرد، تكليف بلوككهاى كرسى است. تكليف بلوككهاى كرسى (كرسى، 19VY) يكك تست قدرتمند براى نورولوزيست هاى بالينى، روان شناسان تحولى و شناختى

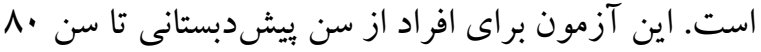
سالكى قابل اجراست. تكليف بلوككهاى كرسى در بررسى اختلالات يادگيرى، عقبماندگى ذهنى، سندرم كورساكف و اختلالات بيشرونده مانند آلزايمر و هانتينگتون و ساير اختلالات عصب روانشناختى كاربرد دارد. شكل اوليه بلو ككهاى كرسى شامل 9 مكعب است

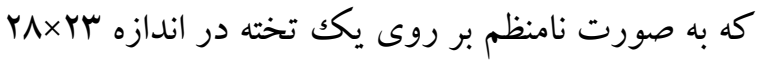
جيده شده بودند. يكك آيتم به آزمودنى ارائه مى cm

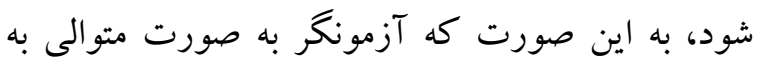
يكك سرى از 9 مكعبى كه روى تخته است، اشاره مى كند و آزمودنى بايد همان توالى حر كات را تكرار كند. اين فراخناى مستقيم مىتواند حافظه كوتاهمدت ديدارىفضايى را ارزيابى كند. با زياد شدن تعداد مكعب ها و با افزايش ييجيدگى ترتيب آنها، آيتمها مشكل تر خواهند

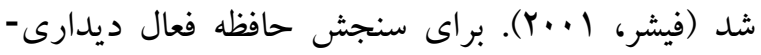
فضايى، از آزمودنى خواسته مىشود كه برعكس توالى عناصرى كه توسط آزمونگر نشان دادهشده است رابه اين معنا كه عنصر آخر بهعنوان عنصر اول توالى و عنصر اول

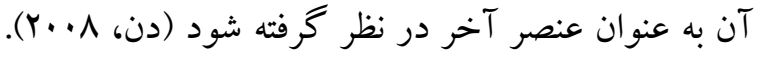


ارقام مستقيم و فراخناى ارقام معكوس به صورت فردى كرفته شد. براى كود كان عادى نيز يس از انتخاب نمونه ها با مراجعه به يكك اتاق بدون سر و صدا و داراى نور كافى در مركز ييش دبستانى تكاليف مورد نظر اجرا شد.

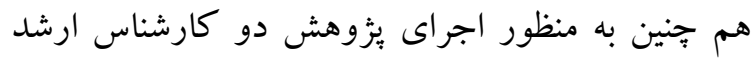
روان شناسى كه با اجراى آزمون ها آشنايى داشتند محققان را يارى كردند. لازم به ذكر است كه از والدين كودكان اوتيسم و عادى با كمك مسئولان مراكز ييشدبستانى و اوتيسم به منظور شركت كردن كود كانشان در يزٔوهش اجازه كتبى گرفته شد.

يافته ها در اين بخش ميانگين و انحراف معيار دو گروه اوتيسم و عادى در نمره كل حافظه فعال و مؤلفههاى سه كانه آن، ارائه شده است.
بنابر اين در مجموع اكر آزمودنى كمتر از هY امتياز بكيرد

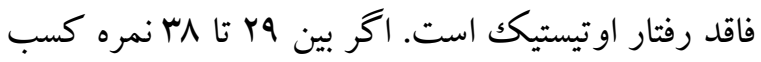
كند، داراى رفتار اوتيستيك ضعيف است. بين نمره یم تا 91 اوتيستيك متوسط است و از نمره VV به بالا فرد دجار اوتيستيك شديد مىباشند؛ و ضريب پايايى آن سه/•

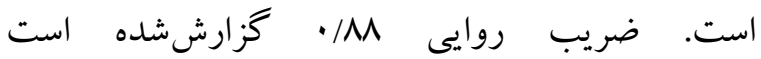
(يارمحمديان، 1HMM). در يثوهش حاضر به منظور اطمينان از تشخيص، والدين كودكان اوتيسم مقياس ارزيابى رفتارهاى اوتيستيكك را براى كود كان خود كامل كردند و سبس اين مقياس ها توسط بُزوهشگ ان نمره كذارى گرديد. r. ابتدا با مراجعه به دو مركز اوتيسم شهر اصفهان كودك اوتيسم F-4 سال انتخاب شدند. به منظور تائيد تشخيص اوتيسم در كود كان، مقياس ارزيابى رفتارهاى

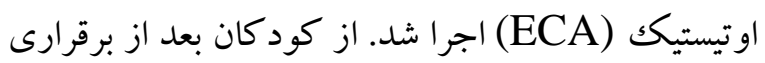
ارتباط با آن ها، تكاليف بلوكك هاى كرسى، فراخناى

\section{جدول 1: شاخص هاى توصيفى حافظه فعال و مؤلفهاى سه كانه آن در كودكان اوتيسم}

\begin{tabular}{|c|c|c|c|c|}
\hline تعداد & حداكثر & حداقل & ميانكين (انحراف معيار) & متغير \\
\hline r. & 19 & r & $(Y / I Y) \quad V / A$. & نمره كل حافظه فعال \\
\hline r. & v & r & $(1 / V \mu) r / V r$ & حلقه واج شناختى \\
\hline$r$. & F & · & سח/r (1/01) & مجرى مر كزى \\
\hline$r$ r. & $\wedge$ & . & $(1 / 9 Y) r / \% q$ & الخُى ديدارى فضايى \\
\hline
\end{tabular}

جدول r: شاخص هاى توصيفى حافظه فعال و مؤلفههاى سه كانه آن در كود كان عادى

\begin{tabular}{|c|c|c|c|c|}
\hline تعداد & حداكثر & حداقل & ميانكين (انحر اف معيار) & متغير \\
\hline r. & rV & $\wedge$ & $(\Delta / 99) 19 / 90$ & نمره كل حافظه فعال \\
\hline r. & ir & r & $(r / \cdot F) 9 / 90$ & حلقه واجشناختى \\
\hline r. & $\wedge$ & r & $(1 / 94) \& / 10$ & مجرى مركزى \\
\hline r. & 1. & r & $(Y / / Y) \Delta / \wedge \Delta$ & الخوى ديدارى-فضايى \\
\hline
\end{tabular}



ميانگين كودكان عادى در نمره كل حافظه فعال و نتايج جداول ا و r ميانگين و انحراف معيار گرووهاى مؤلفههاى آن بالاتر از كود كان اوتيسم است. اوتيسم و عادى را در نمره كل حافظه فعال و مؤلفهاى سه كانه آن نشان مى دهد. همان گُ نه كه مشاهده مى گردد

جدول "ז: خلاصه نتايج آزمون تحليل واريانس تفاوت كروه ها در نمره كل حافظه فعال

\begin{tabular}{|c|c|c|c|c|c|c|c|}
\hline آمارى & اندازه اثر & سطح معنادارى & $\mathbf{F}$ & مجذانغين & آزادى درجه & مجذوروات & شاخص آمارى \\
\hline.$/ 99$ & . &.$/ \cdot 1$ & $r \mid / \cdot \Lambda$ & SVI/TT & 1 & $9 \mathrm{~g}$ & كروه \\
\hline
\end{tabular}

كه qM درصد واريانس نمره كل حافظه فعال مربوط به عضويت گروهى است. توان آمارى 99/ • و سطح احتمال نزديكك به صفر دلالت بر كفايت حجم نمونه است.
نتايج جدول س حاكى از آن است كه تفاوت معنادارى بين

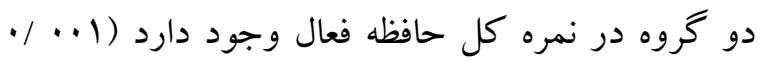
P S

جدول †: خلاصه نتايج آزمون تحليل واريانس تفاوت كروه ها به تفكيك مؤلفه هاى حافظه فعال

\begin{tabular}{|c|c|c|c|c|c|c|c|}
\hline توان & اندازه اثر & معنادارى سطح & $\mathbf{F}$ & مجذانكين & آزادى درجه & مجذورات & آماخصي \\
\hline.$/ 99$ &.$/ 41$ &.$/ .1$ & $r Y / Q Y$ & $9 N / \cdot r$ & 1 & $9 N / \cdot r$ & مؤلفه مجرى \\
\hline$\cdot / 9$ & $\cdot / \pi q$ &.$/ . .1$ & $11 / 4 \lambda$ & $V Y / q 1$ & 1 & $V Y / Q 1$ & مؤلفه حلقه \\
\hline$\cdot / 9$. & - /TD &.$/ .1$ & $11 / 19$ & $\Delta r / Y q$ & 1 & $\Lambda \Gamma / \Upsilon q$ & مؤلفه الكوى \\
\hline
\end{tabular}

بحث و نتيجه تيرى

تحقيق حاضر با هدف بررسى و مقايسه مؤلفههاى حافظه فعال در كود كان اوتيسم و عادى صورت كرفت. نتايج يثوهش حاكى از آن بود كه تفاوت معنادارى بين دو كروه در مؤلفههاى مجرى مركزى، حلقه واجشناختى و

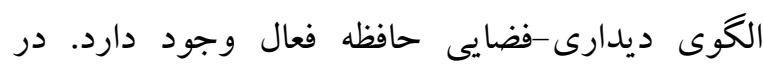
حقيقت بايد كفت كه كودكان اوتيسم در مؤلفههاى
نتايج جدول F حاكى از آن است كه تفاوت معنادارى بين دو گروه در مؤلفههاى مجرى مركزى، حلقه واجشناختى و الخُى ديدارى-فضايى حافظه فعال وجود دارد (1)

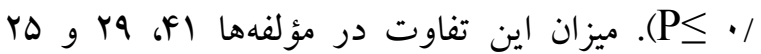
درصد است. هم جنين توان آمارى 99/ • ، •9/ • و •9/ • و سطح احتمال نزديك به صفر دلالت بركفايت حجم نمونه است. 
كود كان اوتيسم نتيجه مشكلات زبانى در اين كود كان

$$
\text { است (اسكاج و مارى ايجستى، Y) (Y). }
$$

در تبيين اين يافته ها مى توان كفت حافظه فعال با فر آيندهاى مربوط به كاركردهاى اجرايى بر يكديخر اثر ين

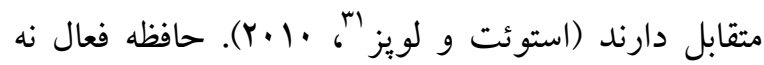
تنها مستقيماً بر كاركردهاى اجرايى تأثير مى گذارد، بلكه در شرايط خاص، خود حافظه فعال بهوسيله ساير فر آيندهاى مربوط به كاركردهاى اجرايى مورداستفاده قرار مى گيرد يا راهاندازى مى شود. حافظه فعال تحت تأثير توجه، بازدارى، انعطافيذيرى و برنامهريزى است و و

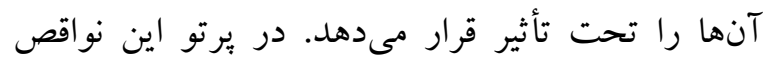

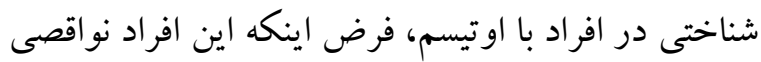
نيز در حافظه فعال داشته باشند، منطقى است (كورت،

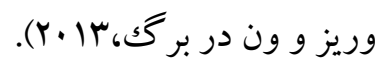

از سوى ديخر لازم به ذكر است، مطالعاتى كه به بررسى ونى حافظه فعال در افراد با اختلال اوتيسم پِرداخته اند يافتهاى ضد و نقيضى دارند. در حالى كه مطالعات متعدد به كرات اختلال حافظه فعال را در اين كروه از

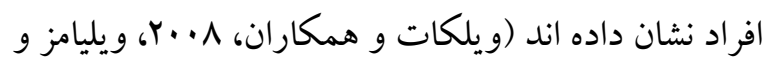

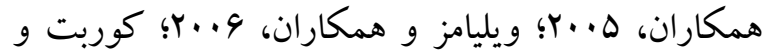

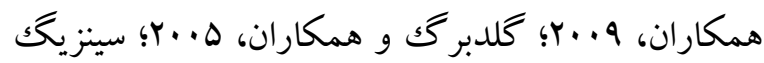

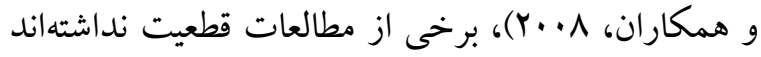

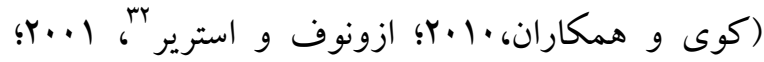

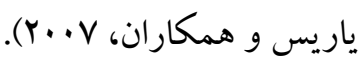

عواملى مختلفى ممكن است به اين ناهماهنكى كمك كند. يكى از اين عوامل انتخاب گروه هدف و مقايسه است. همانطور كه روسو و ديخران (Y.V) بيان مى كنند، اختلال عملكرد حافظه فعال در ارتباط با اوتيسم
حافظه فعال نسبت به كود كان عادى عملكرد يايينترى

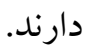
اين يافتها با نتايج تحقيقات گوناگون دال بر وجود نقايص حافظه فعال در افراد با اختلال اوتيسم، همخوانى دارد (ويلكات و همكاران، ^^•r، ويليامز و همكاران،

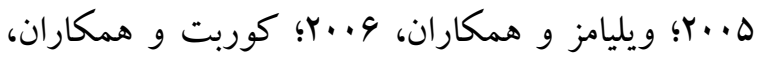

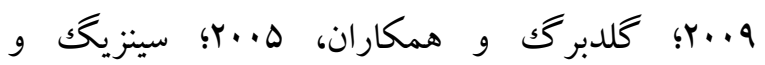
همكاران، 1.+r). مطالعات مختلف حاكى از آن است كه افراد اوتيسم مشكلات حافظه فعال را تجربه مى كنند. شكايت رايجى كه والدين دارند اين است كه فرزند اوتيسم آنها نمىتواند راهنمايى ها يا فرمانها را اجرا كند. حتى كود كانى كه درك شنيدارى و شفاهى آنها رشد خوبى دارد، به نظر مىرسد اين قبيل مشكلات در اجراى دستورالعملها را نشان مىدهند. افراد داراى اختلال اوتيسم بهويزه وقتى بهيكباره بيش از يك رسك دستور العمل به آنها داده مىشود در تبعيت از همه آنها مشكلدارند. اين امر يك مشكل حافظه فعال است كه

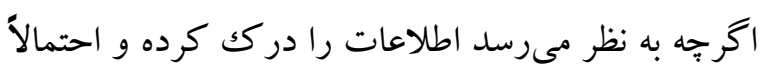
ذخيره مى كنند، ليكن انتقال به منظور تغيير (دستكارى) و

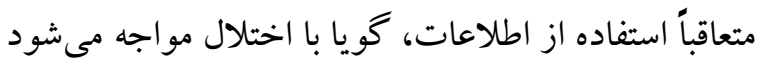

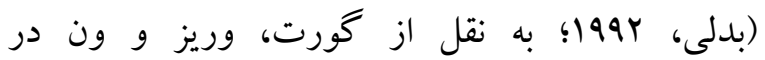

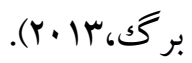
به نظر مىرسد كه مشكلات زبانى و مشكلات هوشى در كودكان اوتيسم عملكرد انواع حافظه فعال را در اين كودكان تحت تأثير قرارمى دهد. با توجه به اينكه تئورىهاى جديد هوش بر رابطه بين اين نوع از حافظه و هوش تأكيد مى كنند. در حقيقت نقايص مؤلفهاى نوري ديدارى-فضايى و حلقهى واجشناختى حافظه فعال در

\footnotetext{
31 - Stoet \& López

32 - Strayer
} 
با در نظر كرفتن نتايج يثوهشهاى مرتبط با عملكرد حافظه فعال در كودكان اوتيسم مىتوان در نهايت نتيجه گيرى كرد كه تحقيقات متعدد رابطهى قوى بين حافظه فعال، زبان و علائم اختلال اوتيسم را نشان داده اند كه اين بثوهش ها بر مزاياى مداخلات مبتنى بر مؤلفههاى حافظه فعال در اين كود كان تأكيد مى كنند (اسكاج و و

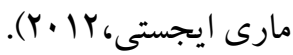

\section{References}

American Psychiatric Association. (2013). Diagnostic and statistical manual of mental disorders (5th Ed.). Washington, DC: Author.

Baddeley, A., (2010). Working memory. Current Biology, 20(4), 136-141.

Baddeley, A.D. (2006). Working memory: An overview. In S.J. Pickering (Ed.).Working memory and education (pp. 1-31). Burlington, MA: Academic Press.

Baio, J. (2012). Prevalence of autism spectrum disorders-Autism and developmental disabilities monitoring network, 14 sites, United States, 2008. Surveillance summaries, Morbidity and Mortality Weekly Report. Center for disease control and prevention.

Baron-Cohen, S. (1991). Precursors to a theory of mind: Understanding attention in others. In A. Whiten (Ed.), Natural theories of mind: Evolution, development and simulation of everyday mindreading (pp. 233-251). Cambridge, MA: Basil Blackwell.

Bennetto, L., Pennington, B. F., \& Rogers, S. J. (1996). Intact and impaired memory functions in autism. Child Development, 67 (4), 18161835.

Brunsdon, V. E. A., Colvert, E., Ames, C., Garnett, T., Gillan, N., Hallett, V.,Happé, F. (2015). Exploring the cognitive features in children with autism spectrum disorder, their
اغلب زمانى مشاهده مىشود كه مطالعات شامل يك كروه مقايسه متشكل از افراد عادى باشند، اما زمانى كه كرووه مقايسه نمونه ایى از افراد با كمتوانى ذهنى است عملكرد حافظه فعال در افراد با اختلال اوتيسم دست

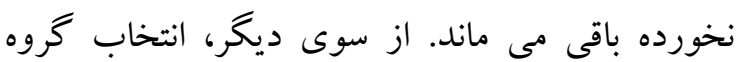
اوتيسم بسيار مهم است. اكثر شركت كنند كان اوتيسم در تحقيقات مربوط به حافظه فعال، افراد مبتلا به اختلال طيف اوتيسم با عملكرد بالا بوده اند كه برخى متخصصين

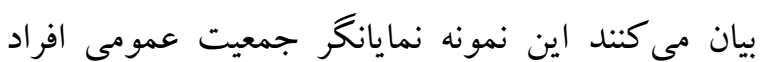

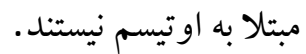
در نهايت، تكاليف مورد استفاده براى اندازه كيرى ليستد مؤلفهاى حافظه فعال همجينين مى تواند بر نتايج حاصل از

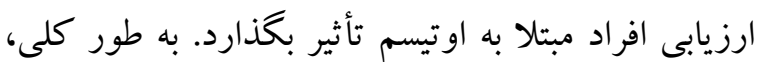
مطالعاتى كه تكاليف مربوط به فراخنا را به كار گرفته اند، دريافتند كه افراد مبتلا به اوتيسم به طور قابلتوجهى

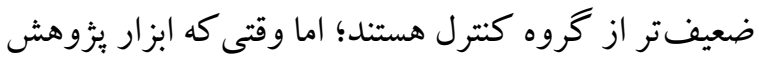
شامل دست كارى اطلاعات (مانندم-back) باشد، تفاوتهاى گروهى مشاهده نشده است (لاندا و و

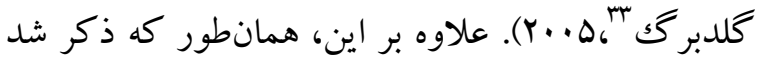
شواهدى وجود دارد كه بار تكاليف حافظه فعال نقش مهمى را در اين بزوهشها ايفا مى كند. وقتى بار حافظه فعال حداقل است، افراد داراى اوتيسم هيج اختلالى در

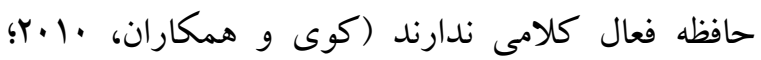

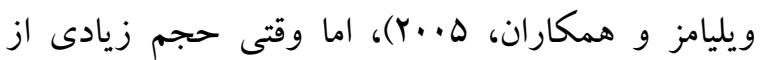
اطلاعات بيّجيده بايد بردازش شود، اين افراد نواقص حافظه فعال كلامى را نشان مىدهند (لاندا و و

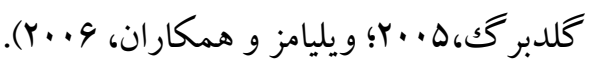

\footnotetext{
${ }^{33}$ - Landa, \& Goldberg
} 
co-twins,and typically developing children within a population-based sample. Journal of Child Psychology and Psychiatry, 56(8), 893-902.

Causton-Theoharis, J., Ashby, C., \& Cosier, M. (2009). Islands of loneliness: Exploring social interaction through the autobiographies of individuals with autism. Intellectual and Developmental Disabilities, 47 (2), 84-96.

Chan, R. C. K., Shum, D., Toulopoulou, T., \& Chen, E. Y. K. (2008). Assessment of executive functions: Review of instruments and identification of critical issues. Archives of Clinical Neuropsychology, 23, 201-216.

Cui, J., Gao, D., Chen, Y., Zou, X., \& Wang, Y. (2010). Working memory in early-school-age children with Asperger's syndrome. Journal of Autism and Developmental Disorders, 40 (8), $958-967$.

Dehn, M.J. (2008). Working memory and academicleaming. New Jersey: Wiley.

Gabig, C. S. (2008). Verbal working memory and story retelling in school-age children with autism. Language, Speech, and Hearing Services in Schools, 39 (4), 498-511.

Ganz, J. B., Davis, J. L., Lund, E. M., Goodwyn, F. D., \& Simpson, R. L. (2011). Metaanalysis of PECS withindividuals with ASD: Investigation of targeted versus non-targeted outcomes, participant characteristics, and implementation phase. Research in DevelopmentalDisabilities, 33 (2), 406-418.

Geurts, H.M., de Vries, M ., van den Bergh., S. F. W. M (2013). Executive Functioning Theory and Autism, Handbook of executive functioning (pp 121-141). Springer Publication.

Hughes, C., Russell, J., \& Robbins, T. W. (1994). Evidence for executive dysfunction in autism. Neuropsychologia, 32, 477-492.

Jordan, A., Carlile, O., \& Stack, A. (2003). Approaches to learning: A Guide for educators. Translated by Elahe Hejazi and
Roohollah Shahabi. Tehran University Press. [Persian]

Kokubo, N., Inagaki, M., Gunji, A., Kobayashi, T., Ohta, H., Kajimoto, O., \& Kaga, M. (2012). Developmental change of visuospatial working memory in children: Quantitative evaluation through an Advanced Trail Making Test. Brain \& Development, 1, 7-14.

Landa, R. J., \& Goldberg, M. C. (2005). Language, social, and executive functions in high functioning autism: A continuum of performance. Journal of Autism and Developmental Disorders, 35, 557-573.

Malekpour, M., Aghababaei, S., \& Abedi, A. (2013). Working memory and learning disabilities. Intemational Journal of Developmental Disability, 59 (1), 35-46.

Nejati, V., \& Izadi-Najafabadi, S. (2012). Comparison of executive functions in highfunction autistic children and their typical matched peers. Journal of Research in Rehabilitation Sciences. 8, 1: 28-39. [Persian]

Ozonoff, S., \& McEvoy, R. E. (1994). A longitudinal study of executive function and theory of mind development in autism. Development and Psychopathology, 6, 415431.

Ozonoff, S., \& Strayer, D. L. (2001). Further evidence of intact working memory in autism. Journal of Autism and Developmental Disorders, 31 (3), 257-263.

Ozonoff, S., Pennington, B. F., \& Rogers, S. J. (1991). Executive function deficits in highfunctioning autistic individuals: Relationship to theory of mind. Journal of Child Psychology and Psychiatry, 32, 1081-1105.

Robert, G., Quach, J., Gold, L., Anderson, P., Richard, F., Mensah, F., Ainley, J., Gathercole, S., Wake, M. (2011). Can improving working memory prevent academic difficulties? A school based 
randomized controlled trail. BMC pediatrics, 14, 65-76.

Russo, N., Flanagan, T., Iarocci, G., Berringer, D., Zelazo, P. D., \& Burack, J. A. (2007). Deconstructing executive deficits among persons with autism: Implications for cognitive neuroscience. Brain and Cognition, $65,77-86$.

Stoet, G., \& López, B. (2010). Task-switching abilities in children with autism spectrum disorder. The European Journal of Developmental Psychology, 8 (2), 244-260.

Terrett G1, Rendell PG, Raponi-Saunders S, Henry JD, Bailey PE, Altgassen M. (2013). Episodic future thinking in children with autism spectrum disorder. Joumal of Autism and Developmental Disorder, 43, 2558-2568.

Verté, S., Geurts, H. M., Roeyers, H., Oosterlaan, J., \& Sergeant, J. A. (2006b). The relationship of working memory, inhibition, and response variability in child psychopathology. Journal of Neuroscience Methods, 151 (1), 5-14.

Willcutt, E. G., Sonuga -Barke, E. J. S., Nigg, J. T., \& Sergeant, J. A. (2008). Recent developments in neuropsychological models of childhood psychiatric disorders. Advances in Biological Psychiatry, 24, 195-226.

Williams, D. L., Goldstein, G., \& Minshew, N. J. (2006). The profi le of memory function in children with autism. Neuropsychology, 20 (1), 21-29.

Williams, D., Goldstein, G., Carpenter, P., \& Minshew, N. (2005). Verbal and spatial working memory in autism. Journal of Autism and Developmental Disorders, 35 (6), 747-756.

Yasuda, Y., Hashimoto, R., Ohi, K., Yamamori, H., Fujimoto, M., Umeda- Yano, S.Takeda, M. (2014). Cognitive inflexibility in Japanese adolescents and adults with autism spectrum disorders. World Joumal of Psychiatry, 4(2), 42e48.

Yerys, B. E., Hepburn, S. L., Pennington, B. F., \& Rogers, S. J. (2007). Executive function in preschoolers with autism: Evidence consistent with a secondary deficit. Joumal of Autism and Developmental Disorders, 37 (6), 1068 1079 . 